\title{
IMPLEMENT POLICY ON STUDENT SCIENTIFIC RESEARCH AT VIETNAM UNIVERSITIES AND EDUCATIONAL INSTITUTIONS TODAY: ISSUES TO DISCUSS
}

\author{
Nguyen Thi Hoa ${ }^{1 *}$, Dinh Tran Ngoc Huy ${ }^{2}$, Tran Van Trung ${ }^{1}$ \\ 1*Thu Dau Mot University, Binh Duong Vietnam; \\ ${ }^{2}$ Banking University HCMC, Ho Chi Minh city Vietnam and International University of Japan, Japan; \\ *Corresponding Author Nguyen Thi Hoa, e-mail: hoant.khql@tdmu.edu.vn;
}

Received November 2021; Accepted December 2021; Published January 2022;

DOI: https://doi.org/10.31407/ijees12.113

\begin{abstract}
Form the time students are involved in studying at universities they can engage in scientific clubs. Hence, the issue of scientific research for students at higher education institutions in Vietnam today is an extremely urgent and important issue. Scientific research not only enhances the discovery and understanding of knowledge for students, but also is a measure of the training quality of higher education institutions today. Therefore, higher education institutions need to have appropriate scientific research policies to promote as well as encourage students to participate in scientific research activities. The study findings suggest that good policy of scientific research of students is the viewpoint and policy of the management agencies on scientific research towards students, aiming to develop research passion as well as improve the current training quality at the university. Schools.
\end{abstract}

Key words: student scientific research, higher education, Vietnam universities, Binh Duong province. 